\title{
Consumption: New Data and Old Puzzles
}

THE RATE OF GROWTH of real consumption expenditures accelerated in the third quarter of 1968 , precisely the quarter in which the 10 percent tax surcharge first became effective. This development contradicts the majority of the forecasts in existence at that time, and marks the end of the first Golden Age of modern forecasting. It is now well known that consumer spending was virtually the only source of growth in the third quarter of 1968 - indeed, real final sales, excluding consumption, rose by only $\$ 0.3$ billion, while consumption jumped by $\$ 9.2$ billion (1958 dollars). In the fourth quarter of 1968 , while the rest of the domestic economy went on a spending spree, consumer expenditures actually fell in real terms. Sad to say, this did not mark the consumers' return to "normalcy." One quarter later, with real disposable income rising by a bare half-billon dollars under the load of retroactive surcharge liabilities, consumer spending jumped by more than $\$ 5^{1 / 4}$ billion (1958 dollars). Those analysts who focus attention on the stability of the saving rate must surely have turned paranoid during the past few years.

In point of fact no serious forecaster counts on any inherent stability in the saving rate. It is merely the residual item in a complex process of expenditure determination. It is precisely this process that economists have long attempted to measure. The important question-for both forecasting and policy analysis-is whether the recent behavior of consumer spending merely contains a few instances of "loud noise," or represents a whole new regime that economists are ill prepared to analyze. If the latter possibility 
is rejected, these instances of apparently aberrant behavior can be turned to advantage in identifying and applying important marginal alterations to a generally sound framework of analysis.

Within the aggregate of consumption expenditures in the national income accounts, economists have long considered spending on nondurables and services the most readily predictable and most nearly "nailed down" by economic theory. Surely it was this component that Keynes had in mind in his discussions of the propensity to consume. The next section of this paper attempts to show that the difficulties involved in explaining the recent pattern of spending on nondurables and services are indeed quite localized. The evidence does not seem to point to any fundamental inadequacy of the commonly employed explanatory techniques-at least none beyond those long well known.

The third section of the paper turns to consumer durables and reports on an experiment in which a wealth variable is employed in an attempt to shed additional light on this volatile category of expenditure.

\section{Econometric Prediction of Nondurables and Services}

Three quarterly econometric models of the U.S. economy were used to assess the degree to which spending on nondurables and services has deviated from recent norms over the past three years. The Wharton model, the FED-MIT-PENN (FMP) model, and the University of Michigan's DHL-III model were all turned loose on the data. ${ }^{1}$ Results are reported in Table 1. For each model, the table contains, by quarter, the difference between real expenditures (measured in 1958 dollars) and expenditures predicted by the model's equation employing the actual values of all determining variables. In addition to these errors, or static residuals, for a single

1. Michael K. Evans and Lawrence R. Klein, Programmed by George R. Schink, The Wharton Econometric Forecasting Model (University of Pennsylvania, Wharton School of Finance and Commerce, Economics Research Unit, 1967); Albert Ando and Franco Modigliani, "Econometric Analysis of Stabilization Policies," American Economic Association, Papers and Proceedings of the Eighty-first Annual Meeting, 1968 (American Economic Review, Vol. 59, May 1969, pp. 296-314); and Saul H. Hymans and H. T. Shapiro, The DHL-III Quarterly Econometric Model of the U.S. Economy (University of Michigan, Research Seminar in Quantitative Economics, 1970). The author expresses his gratitude to all the model engineers who provided data for this analysis. 


\section{Table 1. Comparison of Residuals of Equations Predicting Consumer Expenditures on Nondurables and Services, Selected Econometric Models, 1967-69}

Billions of 1958 dollars

\begin{tabular}{|c|c|c|c|c|c|c|}
\hline \multirow{2}{*}{\multicolumn{2}{|c|}{$\begin{array}{c}\text { Year } \\
\text { and } \\
\text { quarter }\end{array}$}} & \multicolumn{3}{|c|}{ Static residuals ${ }^{\mathrm{a}}$} & \multicolumn{2}{|c|}{$\begin{array}{c}\text { Four-quarter dynamic } \\
\text { residuals }^{\mathrm{a}}\end{array}$} \\
\hline & & $D H L-I I I$ & Wharton & $F M P$ & $D H L-I I I$ & $F M P$ \\
\hline 1967 & $\begin{array}{l}1 \\
2 \\
3 \\
4\end{array}$ & $\begin{array}{l}+2.1 \\
-0.7 \\
-0.8 \\
-1.7\end{array}$ & $\begin{array}{r}\text { n.a. } \\
\text { n.a. } \\
\text { n.a. } \\
-4.0\end{array}$ & $\begin{array}{l}+2.3 \\
-0.6 \\
-3.0 \\
-3.4\end{array}$ & $\begin{array}{l}+2.1 \\
+1.3 \\
+0.4 \\
-1.3\end{array}$ & $\begin{array}{l}+2.3 \\
+0.8 \\
-2.5 \\
-5.0\end{array}$ \\
\hline 1968 & $\begin{array}{l}1 \\
2 \\
3 \\
4\end{array}$ & $\begin{array}{l}+2.7 \\
-1.9 \\
+3.1 \\
-3.2\end{array}$ & $\begin{array}{l}-0.6 \\
-2.4 \\
+0.6 \\
-3.5\end{array}$ & $\begin{array}{l}+1.3 \\
-2.7 \\
-0.8 \\
-4.4\end{array}$ & $\begin{array}{l}+2.7 \\
+0.7 \\
+3.7 \\
+0.4\end{array}$ & $\begin{array}{l}+1.3 \\
-1.9 \\
-2.0 \\
-5.5\end{array}$ \\
\hline 1969 & $\begin{array}{l}1 \\
2 \\
3 \\
4\end{array}$ & $\begin{array}{l}+1.5 \\
-1.3 \\
-2.8 \\
-0.3\end{array}$ & $\begin{array}{l}-2.7 \\
-3.8 \\
-6.0 \\
-4.8\end{array}$ & $\begin{array}{r}+0.2 \\
-1.2 \\
\text { n.a. } \\
\text { n.a. }\end{array}$ & $\begin{array}{l}+1.5 \\
+0.2 \\
-2.7 \\
-2.8\end{array}$ & $\begin{array}{r}+0.2 \\
-1.1 \\
\text { n.a. } \\
\text { n.a. }\end{array}$ \\
\hline \multicolumn{7}{|c|}{ Root mean square errors ${ }^{b}$} \\
\hline $\begin{array}{l}1967 \\
1968 \\
1969\end{array}$ & & $\begin{array}{l}1.4 \\
2.8 \\
1.7\end{array}$ & $\begin{array}{l}\text { n.a. } \\
2.1 \\
4.5\end{array}$ & $\begin{array}{l}2.6 \\
2.7 \\
\text { n.a. }\end{array}$ & $\begin{array}{l}1.4 \\
2.3 \\
2.1\end{array}$ & $\begin{array}{l}3.0 \\
3.2 \\
\text { n.a. }\end{array}$ \\
\hline $\begin{array}{l}1967 \\
1968 \\
1969\end{array}$ & & $\begin{array}{l}-0.3 \\
+0.2 \\
-0.7\end{array}$ & $\begin{array}{c}\text { Mean a } \\
\text { n.a. } \\
-1.5 \\
-4.3\end{array}$ & $\begin{array}{c}\text { raic err } \\
-1.2 \\
-1.6 \\
\text { n.a. }\end{array}$ & $\begin{array}{l}+0.6 \\
+1.9 \\
-1.0\end{array}$ & $\begin{array}{r}-1.1 \\
-2.0 \\
\text { n.a. }\end{array}$ \\
\hline
\end{tabular}

Sources: Author's estimates using the econometric models developed in Saul H. Hymans and H. T. Shapiro, The DHL-III Quarterly Econometric Model of the U.S. Economy (University of Michigan, Research Seminar in Quantitative Economics, 1970); Michael K. Evans and Lawrence R. Klein, Programmed by George R. Schink, The Wharton Econometric Forecasting Model (University of Pennsylvania, Wharton School of Finance and Commerce, Economics Research Unit, 1967); and Albert Ando and Franco Modigliani, "Econometric Analysis of Stabilization Policies," American Economic Association, Papers and Proceedings of the Eighty-first Annual Meeting, 1968 (American Economic Review Vol. 59 May 1969, pp. 296-314).

n.a. Not available. Data problems made it necessary to begin in 1967:4 for the Wharton model and end in 1969:2 for the FMP model.

a. All residuals are defined as actual expenditure minus predicted expenditure.

b. The square root of the sum of the squared residuals.

quarter, the table gives dynamic residuals for the DHL-III and FMP models.

The dynamic residuals are the errors made in the equations when their job is made tougher by the withholding of information on how well they 
have been doing in recent quarters. In the first quarter of each calendar year, the equation is, in effect, allowed to know the actual value of consumption of nondurables and services for the fourth quarter of the previous year. For the second quarter, however, the equation is given no actual consumption data for the first quarter; the only information about consumption for the first quarter is the value previously predicted for that quarter. For the third and fourth quarters, as well, the equation is given its own previous predictions, but no further information on actual consumption.

The models are different enough to provide rather varied results, but a number of consistencies emerge. Consumer spending on nondurables and services was abnormally low in the second half of 1967 . Following a strong surge in the first quarter of 1968, it was again low in the following quarter - the quarter immediately preceding imposition of the tax surcharge. Whether this consumer hesitancy represented a strike against inflation, the anticipation of a tax increase, or something entirely different, it clearly is not captured in the equations of any of the three models. The FMP model is the only one not caught napping by the jump in consumption in the third quarter of 1968. This result has generally been attributed to the presence of household wealth or net worth in the FMP model. While the surcharge had a strong restraining effect on disposable income, it obviously had little or no immediate impact on household wealth. A model that put some weight on wealth - and relatively less on income-would therefore anticipate a much smaller initial impact from the surcharge. However, the complete reversal of consumer behavior in the fourth quarter of 1968, while poorly predicted by all three models, spells disaster for the FMP model. The same influence of wealth that correctly maintains consumer spending in the third quarter prevents the expenditure rate from dropping appropriately in the fourth quarter. It's all in where you want to make your mistakes!

On the whole, 1969 seems to be a more nearly normal year for nondurables and services as far as the DHL-III and FMP models are concerned. ${ }^{2}$ While errors are clearly in evidence, they are back within limits tolerable to most forecasters. It is precisely this (ex post) improvement in 1969-following the major, but not intractable, problems of 1968-that counsels against any inference of "new" consumer behavior relative to

2. The Wharton model has developed a definite drift in 1969 , but this may be a problem related to data revision. 
nondurables and services. Rather, it underscores the presence of motivational and expectational factors, which remain largely outside the scope of any model.

\section{Auto Expenditures and the Wealth Variable}

Table 2 presents single-quarter static residuals for the (ex post) prediction of consumer durable spending by the FMP and DHL-III models. In the FMP model, expenditures on durable goods depend positively on

\section{Table 2. Comparison of Residuals of Equations Predicting Consumer Expenditures on Durables, Selected Econometric Models, 1967-69}

Billions of 1958 dollars

\begin{tabular}{|c|c|c|c|c|}
\hline \multirow{2}{*}{\multicolumn{2}{|c|}{$\begin{array}{l}\text { Year and } \\
\text { quarter }\end{array}$}} & \multicolumn{3}{|c|}{ Static residuals } \\
\hline & & $D H L-I I I$ & $F M P(1)^{\mathrm{b}}$ & $F M P(2)^{\mathrm{b}}$ \\
\hline 1967 & $\begin{array}{l}1 \\
2 \\
3 \\
4\end{array}$ & $\begin{array}{l}-3.3 \\
+0.8 \\
-1.0 \\
+1.2\end{array}$ & $\begin{array}{l}-2.3 \\
+2.2 \\
-1.6 \\
-1.4\end{array}$ & $\begin{array}{l}-1.8 \\
+1.8 \\
-2.0 \\
-1.9\end{array}$ \\
\hline 1968 & $\begin{array}{l}1 \\
2 \\
3 \\
4\end{array}$ & $\begin{array}{l}+0.1 \\
+1.0 \\
+4.0 \\
+2.5\end{array}$ & $\begin{array}{r}-0.2 \\
-0.3 \\
+3.0 \\
0.0\end{array}$ & $\begin{array}{l}+0.4 \\
-1.2 \\
+3.4 \\
-1.2\end{array}$ \\
\hline 1969 & $\begin{array}{l}1 \\
2 \\
3 \\
4\end{array}$ & $\begin{array}{l}+3.8 \\
+4.3 \\
+0.8 \\
+2.2\end{array}$ & $\begin{array}{r}+1.5 \\
+2.7 \\
\text { n.a. } \\
\text { n.a. }\end{array}$ & $\begin{array}{r}+2.3 \\
+1.9 \\
\text { n.a. } \\
\text { n.a. }\end{array}$ \\
\hline $\begin{array}{l}1967 \\
1968 \\
1969\end{array}$ & & $\begin{array}{c}\text { oot mean } \\
1.9 \\
2.4 \\
3.1\end{array}$ & $\begin{array}{c}\text { re errors } \\
1.9 \\
1.5 \\
\text { n.a. }\end{array}$ & $\begin{array}{l}1.9 \\
1.9 \\
\text { n.a. }\end{array}$ \\
\hline $\begin{array}{l}1967 \\
1968 \\
1969\end{array}$ & & $\begin{array}{c}\text { Mean alge } \\
\quad-0.6 \\
+1.9 \\
+2.8\end{array}$ & $\begin{array}{r}\text { errors } \\
-0.8 \\
+0.6 \\
\text { n.a. }\end{array}$ & $\begin{array}{r}-1.0 \\
+0.3 \\
\text { n.a. }\end{array}$ \\
\hline
\end{tabular}

Source: Author's estimates using the econometric models described in Hymans and Shapiro, DHL-III Quarterly Econometric Model, and Ando and Modigliani, "Econometric Analysis of Stabilization Policies." n.a. Not available. See note to Table 1, p. 119.

a. All residuals are defined as actual expenditure minus predicted expenditure.

b. In FMP(1), the equation uses the actual current value of spending on nondurables and services. In FMP(2), the equation uses the model's own forecast of current spending on nondurables and services.

c. The square root of the sum of the squared residuals. 
current expenditures on nondurables and services. Since the latter is taken to depend on household wealth, the use of this technique is presumably an attempt to include a wealth effect as part of the mechanism determining expenditures on durables. The residuals denoted FMP (1) are obtained by permitting the equation to estimate current spending on durables using the actual current value of spending on nondurables and services. The residuals denoted FMP(2) are obtained by forcing the equation to respond to the model's own forecast of current spending on nondurables and services, thereby incorporating a test of the wealth effect.

The results provide no clear basis for a verdict. Both models operate reasonably well through mid-1968 and then develop a distinct tendency to underestimate durable spending. The underestimation appears to be somewhat less serious in the case of the FMP model. Unlike that model, the DHL-III model treats autos separately from durables and the underestimate is attributable essentially in full to the automobile equation. It is reassuring to find the auto sector apparently the culprit; it always has been. ${ }^{3}$

Given the inconclusiveness of the data in Table 2 and the strong advocacy by many economists of a wealth effect, it seemed appropriate to test wealth directly as an aid in predicting auto expenditures.

Specifically, it was decided to permit household net worth-as defined in the FMP model-to be a determinant of the desired stock of autos in the DHL-III auto equation. The FMP net worth variable is a tour de force. Very roughly, it calculates the increase in net worth as the sum of (a) the value of the increase in the housing stock during the previous quarter; (b) the increase in the value of the preexisting housing stock; (c) the value of the increase in the stock of consumer durables during the previous quarter; (d) the increase in the value of the preexisting stock of consumer durables; and (e) capital gains accrued in the stock market.

In its present form, the DHL-III auto equation assumes that disposable income and the unemployment rate are the determinants of the desired stock of autos. Household net worth can easily be added to the list and treated symmetrically with the other determinants. The equation is rather

3. A noticeable-although not overwhelming-part of the underestimate reflects an anachronism of the data: Expenditures on mobile homes are included in the total of auto consumption. In recent years expenditures on mobile homes have risen rapidly and have become large enough to affect the series. 


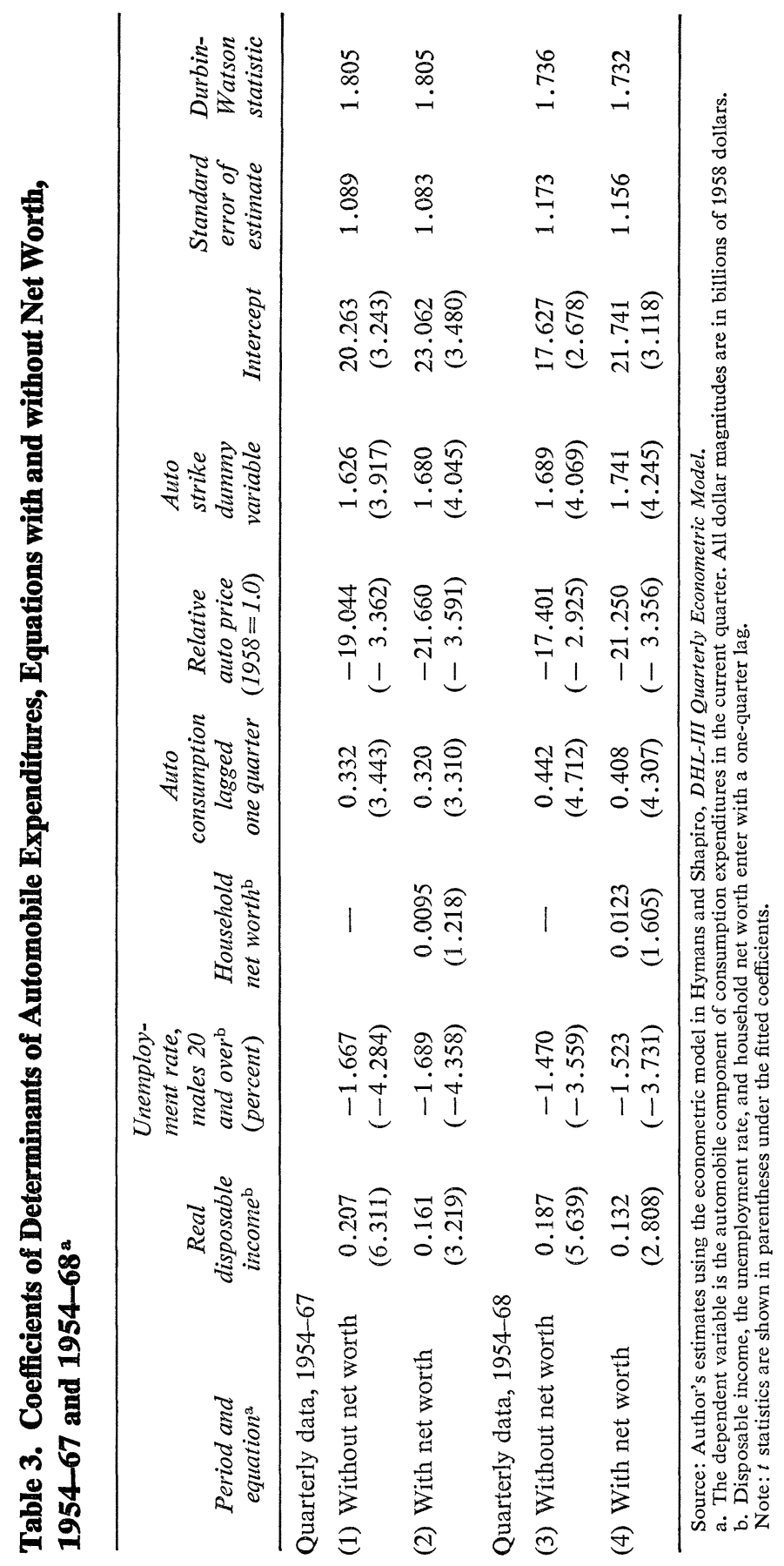


complex and permits a number of possible estimation procedures. ${ }^{4}$ Some of these were tried, and all yielded essentially identical results. Table 3 shows the results of one estimation procedure applied with and without the net worth variable for the periods 1954:1 through 1967:4 and 1954:1 through 1968:4.

The table makes clear that, in the versions without net worth, each variable has a highly significant coefficient. But when the data period is extended to include 1968, the coefficients on income and unemployment fall in absolute value while the coefficient on lagged auto consumption rises. The latter has the interpretation of 1 minus the quarterly rate of adjustment between the actual and desired stock of autos. The tax surcharge in 1968 retards the growth of disposable income and therefore curtails the rate of growth of the desired auto stock. Evidently the only way the strong automobile demand of 1968 can be rationalized is to diminish the rate at which auto expenditures close the gap between the actual and desired stock of automobiles, thereby leaving a larger gap to be filled (ceteris paribus) at any point in time.

The net worth variable is apparently mere window dressing for the 1954-67 sample. Although it lowers the income coefficient, it obviously plays only a minor role in determining the desired auto stock. The situation changes substantially when 1968 is added. The coefficient of net worth approaches statistical significance, and the income coefficient-though still by far the more important—is much reduced. Further, the decline in the adjustment rate is much more modest than that previously noted. The 1968 experience is clearly the source of strength of net worth as an explanatory factor. As a general rule, a variable that depends on an isolated episode for its strength is to be viewed with caution. Table 4 presents evidence to support this view.

Auto equations have generally experienced some difficulty in explaining the 1955-56 and 1961-62 periods as well as the 1967-68 period. Table 4 contains the residuals from equations (3) and (4) of Table 3 for these periods. The net worth version of the equation is slightly inferior in both of the earlier periods and superior in 1967-68. Table 4 also contains the results of extrapolating equations (3) and (4) into 1969. After a superior performance in 1968 , the net worth equation produces generally larger

4. A complete description of the derivation and econometrics of the problem is given in Hymans and Shapiro, DHL-III Quarterly Econometric Model. 
Table 4. Comparison of Residuals of Equations Predicting Automobile Expenditures, with and without Net Worth, Selected Periods, 1955-69

Billions of 1958 dollars

\begin{tabular}{|c|c|c|c|}
\hline & & \multicolumn{2}{|c|}{ Static residuals ${ }^{\mathrm{a}}$} \\
\hline \multicolumn{2}{|c|}{$\begin{array}{l}\text { Year and } \\
\text { quarter }\end{array}$} & \multirow{2}{*}{$\begin{array}{l}\begin{array}{l}\text { 1954-68 equation } \\
\text { without net worth }\end{array} \\
+1.05\end{array}$} & \multirow{2}{*}{$\begin{array}{c}\text { 1954-68 equation } \\
\text { with net worth } \\
+1.00\end{array}$} \\
\hline 1955 & 1 & & \\
\hline & 2 & +1.75 & +1.68 \\
\hline & 3 & +1.38 & +1.54 \\
\hline & 4 & -0.87 & -0.94 \\
\hline 1956 & 1 & -1.73 & -1.70 \\
\hline & 2 & -1.19 & -1.07 \\
\hline & 3 & -1.39 & -1.37 \\
\hline & 4 & +0.51 & +0.51 \\
\hline 1957 & 1 & +0.91 & +1.25 \\
\hline \multirow{2}{*}{\multicolumn{2}{|c|}{$\begin{array}{l}\text { Root mean square error }{ }^{\mathrm{b}} \\
\text { Mean algebraic error }\end{array}$}} & $(1.259)$ & $(1.283)$ \\
\hline & & $(+0.047)$ & $(+0.100)$ \\
\hline 1961 & 3 & -0.45 & -0.77 \\
\hline & 4 & -0.92 & -1.10 \\
\hline 1962 & 1 & -0.76 & -0.90 \\
\hline & 2 & -0.82 & -0.98 \\
\hline & 3 & +0.14 & +0.38 \\
\hline & 4 & +0.70 & +0.98 \\
\hline 1963 & 1 & +0.76 & +0.90 \\
\hline \multirow{2}{*}{\multicolumn{2}{|c|}{$\begin{array}{l}\text { Root mean square error } \\
\text { Mean algebraic error }\end{array}$}} & $(0.696)$ & $(0.885)$ \\
\hline & & $(-0.193)$ & $(-0.213)$ \\
\hline \multirow[t]{4}{*}{1967} & 1 & -3.11 & -2.42 \\
\hline & 2 & +0.22 & +0.24 \\
\hline & 3 & -1.54 & -1.96 \\
\hline & 4 & +0.34 & -0.03 \\
\hline \multirow[t]{4}{*}{1968} & 1 & +0.20 & +0.05 \\
\hline & 2 & -0.06 & +0.37 \\
\hline & 3 & +2.62 & +2.69 \\
\hline & 4 & +1.91 & +1.39 \\
\hline \multirow{2}{*}{\multicolumn{2}{|c|}{$\begin{array}{l}\text { Root mean square error } \\
\text { Mean algebraic error }\end{array}$}} & $(1.687)$ & $(1.544)$ \\
\hline & & $(+0.072)$ & $(+0.041)$ \\
\hline \multirow[t]{3}{*}{1969} & 1 & +1.54 & +1.77 \\
\hline & 2 & +2.12 & +2.02 \\
\hline & 3 & +2.23 & +2.50 \\
\hline
\end{tabular}

Source: Based on equations (3) and (4), Table 3, p. 123.

a. All residuals are defined as actual expenditure minus predicted expenditure.

b. The square root of the sum of the squared residuals. 
underestimates in 1969 because its forecast of auto spending is pulled down by the substantial decline of common stock prices that began late in 1968.

As currently measured and used, the net worth variable is clearly no panacea. It has shifted the dating of the errors, but they persist. Above all, there appears to be no possibility of substituting wealth for income in attempts to explain consumption. If a wealth variable ultimately proves itself, it is most likely to be in the form of a marginal addition to the arsenal of explanatory factors currently in use.

\section{Conclusion}

This exploratory paper cautions against a hasty rejection of received doctrine regarding nondurables and services, but points up the incompleteness of its current empirical formulation. It judges the wealth variable - at least in the experiment conducted - to be little more than a dummy variable, yet surely wealth does count in one way or another. Many questions are raised here. Perhaps the next installment can seek a few answers. 